\title{
Jedność Europy. Kilka uwag o relacjach Wschód-Zachód w Rodzinnej Europie Czesława Miłosza ${ }^{1}$
}

\section{Europe's Unity. Some Remarks on the East-West Relationship in Czesław Miłosz's Native Realm}

\begin{abstract}
This paper traces the evolution of the notion of Europe in Czesław Miłosz's Native Realm. The author points to the antinomy in the image of East and West noticeable at the start of the work and argues that this dichotomy is gradually surpassed by the speaking subject. In the final pages of Native Realm Miłosz gives a definition of the Old Continent as a cultural whole. According to the author, the Polish Nobel Laurate is inspired by the work and ideas of Stanisław Vincenz (expressed, for example, in the essay Krajobraz jako tto dziejów [Lanscape as historical background]).
\end{abstract}

Keywords: Czesław Miłosz, Rodzinna Europa, Native Realm, geocultural notion of Europe, East-West antinomy, Europe's cultural unity, Stanisław Vincenz

Streszczenie: Tematem artykułu jest ewolucja pojęcia Europy w Rodzinnej Europie Czesława Miłosza. Autorka stwierdza antynomiczność obrazu Wschodu i Zachodu na początku wymienionego dzieła, broni jednak tezy o stopniowym pokonywaniu przez jego podmiot tej dychotomii. W zakończeniu Rodzinnej Europy Miłosz formułuje definicję Starego Kontynentu jako kulturowej całości. Polski noblista inspiruje się przy tym - zdaniem autorki twórczością i poglądami Stanisława Vincenza (znanymi między innymi z eseju Krajobraz jako tto dziejów).

Słowa kluczowe: Czesław Miłosz, Rodzinna Europa, geograficzno-kulturowa kategoria Europy, antynomiczność Wschodu i Zachodu, kulturowa jedność Europy, Stanisław Vincenz

1 Pierwsza wersja niniejszego artykułu (Die Einheit Europas. Einige Bemerkungen zum Ost-West-Verhältnis in „Rodzinna Europa”) ukazała się w tomie: Czestaw Mitosz im Jahrhundert der Extreme. Ars poetica - Raumprojektionen - Abgründe - Ars translationis, red. A. Lawaty, M. Zybura, Osnabrück 2013, s. 159-172. Łukaszowi Tischnerowi dziękuję za wnikliwe uwagi do tekstu, które umożliwiły odpowiednie uściślenia i zmiany. 
Tytuł tego dzieła ${ }^{2}$ od początku zdawał się sprawiać jego czytelnikom pewne trudności: przez tłumaczy uważany był najczęściej za nieprzekładalny i bodaj tylko na włoski przetłumaczony został dosłownie jako Europa familiare; raz po raz podnoszono również pytanie, jak też należy rozumieć przymiotnik rodzinna. W pierwszych dekadach krajowej recepcji Rodzinnej Europy dominowała opinia Jana Błońskiego, że książka ta jest „wspomnieniem czy rozważaniem” na temat obszaru byłego Wielkiego Księstwa Litewskiego, tej „dalekiej, oderwanej czy zapomnianej części historycznej Polski, z której pochodził pisarz... Słowo "rodzinna "znaczyłoby więc »ta, gdzie się [Miłosz - dop. M.Z.] urodził»"3. Taka interpretacja tytułu znajduje wsparcie w wyrażonym przez poetę we Wstępie do Rodzinnej Europy zamiarze, że chce on „przybliżyć Europę Europejczykom”. Jednocześnie Błoński dostrzegał w Rodzinnej Europie dzieło, w którym Europa widziana jest jako całość:

Komentarz Miłosza, który mówił o „krajobrazach doznanych już przed chwilą narodzin" i porównuje się z Grekiem wędrującym po rozmaitych miastach imperium... popiera jednak rozumienie rodzicielki jako całości cywilizacyjnej5.

Beata Tarnowska stwierdza natomiast antynomiczny charakter obrazu Europy u Miłosza:

Geograficzno-kulturowa kategoria Europy implikuje w twórczości Miłosza zasadniczy, dychotomiczny podział na Zachód - z centrum w Paryżu - oraz Wschód, mityczne centrum i peryferie ${ }^{6}$.

Również niemieckie tłumaczenie tytułu dzieła - West und Östliches Gelän$d e-$ jest wyrazem podobnej jego wykładni. Jednakże zauważona słusznie przez Tarnowską dychotomiczność w widzeniu Europy u Miłosza nie przeczy stwierdzonej przez Błońskiego integracji, tyle tylko, że ta ostatnia dokonuje się dopiero pod koniec Rodzinnej Europy. Zarówno dychotomia, jak i widoki na zjednoczenie Europy zapowiedziane zostają już we wstępie. Odwiedzając stary dom na szwajcarskim brzegu Lemanu, podmiot dzieła doznaje „podwójnych uczuć, tubylca i cudzoziemca”:

2 Pierwsze wydanie ukazało się w Paryżu w 1959 roku. Wszystkie cytaty pochodzą z następującego wydania: C. Miłosz, Rodzinna Europa, „Dzieła zebrane”, Kraków 2001.

3 J. Błoński, Europa Mitosza [w:] tegoż, Mitosz jak świat, Kraków 1998, s. 181-194, tu s. 182.

4 C. Miłosz, Rodzinna Europa, dz. cyt., s. 13.

5 J. Błoński, dz. cyt., s. 182.

6 B. Tarnowska, Geografia poetycka w powojennej twórczości Czestawa Mitosza, Olsztyn 1996, s. 122. 
Niewątpliwie i tu była moja ojczyzna, ale wyrzekająca się, jakby na mocy narzuconego sobie zakazu, wiedzy o sobie jako całości, dzieląca swoją ludność na rodzinę, skłóconą, ale rodzinę, i ubogich kuzynów ${ }^{7}$.

Wspomniane wyparcie się jest wynikiem politycznych decyzji w Jałcie, które - jak to Miłosz powie w Przypisie po latach - zepchnęły Europę Środkowo-Wschodnią „w ciemności zewnętrzne”" Jednocześnie podmiot Rodzinnej Europy, którego pamięć uczuciowa ożywiona została zapachem przedmiotów na strychu domu, czuje się „niemy”, sparaliżowany i odczuwa „dotkliwość jakiegoś zaniechania" 9 . To zaś oznacza chyba, że i on sam ma coś do nadrobienia, że musi sobie samemu coś wyjaśnić i, jak to jest powiedziane w innym miejscu, potrzebuje to coś „ułożyć w jakim takim porządku” ${ }^{10}$, aby dalsze trwanie przynajmniej mentalnego - podziału Europy nie ciążyło również na nim. Rodzinna Europa jest podjęciem wyzwania, próbą mówienia i o własnej części kontynentu, i o Europie jako całości. Nie chodzi tylko o to, by przybliżyć Europę Środkowo-Wschodnią Zachodowi i opowiedzieć o sobie, lecz także o to, by przemienić traumę w wysiłek twórczy, którego celem jest nowa konfiguracja pamięci kultury po obu stronach żelaznej kurtyny.

Gdzie jednak leży Europa Miłosza, jak należy zdefiniować jej topografię? Przyjrzyjmy się najpierw geograficzno-kulturowej definicji Europy w chronologicznie wcześniejszym utworze Świat. Poema naiwne (1943). Widziana tu przez dzieci z okna i objaśniana przez Ojca Europa to kolejno: Warszawa, Praha, Alpy, Włochy (Rzym) i Francja (Paryż). Pozostałe miejsca mają raczej znaczenie drugorzędne. Ojciec zamyka swoje objaśnienia w następujący sposób: „I inne miasta Paryżowi wtórzą/ Szkłem ozdobione, okute żelazem./ Ale na dzisiaj byłoby za dużo./ Resztę opowiem kiedyś innym razem"11.

Już tutaj zdefiniowana zostaje przestrzeń, która w Europie ma dla Miłosza wyjątkowe, największe znaczenie. Gdzie znajdują się jednak Wilno i litewska ojczyzna poety? Nie są one przecież tożsame z dobrze strzeżoną idyllą dzieciństwa, która stanowi centrum szkatułkowej czy kulistej przestrzeni Świata... ${ }^{12}$ Przestrzeń idylli ma prawa szczególne i nie przynależy do rzeczywistości historycznej,

7 C. Miłosz, Rodzinna Europa, dz. cyt., s. 12.

8 Tamże, s. 6.

9 Tamże, s. 12.

10 Tamże, s. 80: „Mój przykład wystarczy, żeby stwierdzić, jak wielkiego wysiłku wymaga przyswojenie sobie sprzecznych tradycji, norm i zbyt obfitych wrażeń, czyli ułożenie ich w jakim takim porządku”.

11 C. Miłosz, Wiersze tom I, „Dzieła zebrane”, Kraków 2001, s. 200.

12 O modelu przestrzeni w Świecie... pisze Jacek Łukasiewicz (zob. tenże, Przestrzeń „świata naiwnego". O poemacie Czestawa Mitosza "Świat” [w:] Poznawanie Mitosza 2. Część pierwsza 1980-1998, red. A. Fiut, Kraków 2000, s. 129-152. 
w sposób oczywisty nie jest więc częścią Europy ${ }^{13}$. W Świecie... należy do Europy Warszawa, ale dawne Wielkie Księstwo Litewskie - nie. Nie jest to świadome wyłączenie bliższej ojczyzny poety z Europy; Miłoszowi brakuje chyba jeszcze definicji, by ją na tej mapie umieścić i odpowiednio docenienić jej znaczenie.

W Rodzinnej Europie kulturowo-geograficzne pojęcie Starego Kontynentu zmienia się istotnie. Na początku Europa jest podzielona. Pierwsza część, z którą Miłosz się utożsamia i którą zwykle nazywa „Wschodem”, a czasem także „Północą" ${ }^{14}$, a którą ja - w celu uniknięcia terminologicznych kontrowersji nazywać będę Europą Środkowo-Wschodnią, stanowi obszar między Niemcami a Rosją, ze szczególnym podkreśleniem bliższej ojczyzny poety; druga część to Zachód. W Świecie... Europa objaśniona zostaje przez autorytet - Ojca. W Rodzinnej Europie jest oczywiście inaczej. Ponieważ Miłosz w ogóle chętnie myśli sprzecznościami, również myślenie o Europie w tym dziele organizuje się początkowo wokół licznych strukturalnych antynomii. Do najważniejszych należą opozycje: Polska a Litwa, polskość a mniejszości narodowe, Polska, czy raczej Europa, a Rosja, religia a naukowy pogląd na świat, ortodoksyjność a heterodoksyjność, wreszcie Polska, względnie Europa Środkowo-Wschodnia, a Zachód ${ }^{15}$. Ale Rodzinna Europa obejmuje przecież prawie cztery dekady życia Miłosza, a tym samym również podmiotu jego dzieła. I podmiot ten - co dość oczywiste - zmienia się na przestrzeni czasu, a razem z nim ulega modyfikacji jego horyzont poznawczy, zmieniają się jego poglądy i emocje. Można nawet powiedzieć, że mamy w tym dziele kilku bohaterów cząstkowych, będących przedmiotem refleksji - bohater jako dziecko, jako młody mężczyzna, jako dyplomata w służbie komunistycznego państwa oraz instancję nadrzędną, będącą tej refleksji podmiotem; ta ostatnia scharakteryzowana jest jako mężczyzna dojrzały, intelektualista i emigrant ${ }^{16}$. Struktura ta przypomina charakterystyczne dla autobiografii rozszczepienie podmiotu na Ja przeżywające i Ja przypominające sobie dawne losy - szczególnie że w Rodzinnej Europie Ja jako przedmiot refleksji jest „cofnięte" w czasie. Jednak w porównaniu z autobiografią biografia Ja eseistycznego w Rodzinnej Europie jest raczej fragmentaryczna i stosunkowo mało prywatna $^{17}$, gdyż, jak się zdaje, ważniejszy od niej jest rozwijany w Rodzinnej Europie

13 Por. M. Bachtin, Czasoprzestrzeń idylliczna w powieści [w:] tegoż, Problemy literatury i estetyki, tłum. W. Cesluk-Grajewski, Warszawa 1982, s. 447-468.

14 C. Miłosz, Rodzinna Europa, dz. cyt., s. 12.

15 W większości wypadków opozycje te wyodrębniła już Tarnowska (zob. taż, dz. cyt.).

16 Eseistyczne Ja jako podmiot refleksji nazywać będę dalej narratorem; jako bohater określany będzie natomiast przedmiot tej refleksji. Zaznaczam z jednej strony, że mowa tu o literackich konstruktach, z drugiej jednak mam cały czas na uwadze ich bliski związek z autorem.

17 Por. uwagi Renaty Gorczyńskiej o Rodzinnej Europie: „Opisując swoje losy od wczesnego dzieciństwa, przez cały czas podkreśla pan historyczne i społeczne uwarunkowania człowieka, niemal zgodnie z hasłem "Byt kształtuje świadomość. Zastanawiam się, czy uchwycenie typowych procesów nie jest trochę niebezpiecznym zadaniem, bo to, co szczególne w człowieku, zaciera się na rzecz ogólnego” (C. Miłosz, R. Gorczyńska, Podróżny świata. Rozmowy, „Dzieła zebrane”, Kraków 2002, s. 154). 
proces myślowy, który swoją kulminację znajduje w zamykającym dzieło rozdziale Tygrys ${ }^{18}$, przy czym wymienione wyżej pary pojęć, wydające się z początku antynomicznymi, w końcu okazują się wielkościami komplementarnymi ${ }^{19}$.

We Wstępie, Podróży na Zachód oraz Mtodym cztowieku i sekretach Europa Środkowo-Wschodnia i Zachód przedstawiane są jako para antynomiczna. Zachód oceniany jest jednak inaczej w każdej z trzech faz czasu autobiografii podmiotu ${ }^{20}$. Początkowo przeciwieństwo obu części Europy opisywane jest za pomocą binaryzmów „wyższoóć” versus „niższość” oraz „dobrobyt” vs. „bieda” (Wstęp), osąd ten przypisany zostaje jednak raczej społeczeństwom zachodnim niż podmiotowi - to one nie chcą nic wiedzieć o swych „biednych kuzynach”. W następnych rodziałach Rodzinnej Europy przeciwieństwo dobrobytu i biedy występuje też w rozważaniach podmiotu dzieła, dochodzą do niego również kolejne, jak forma i stabilność Zachodu i bezformie oraz wieczna tymczasowość wschodniej peryferii ${ }^{21}$. Młody człowiek, odbywający właśnie swoją pierwszą podróż na Zachód, kojarzy wschodnie peryferie Europy z gorszością i drugorzędnością, ich przeciwieństwa są przezeń uznawane za wyróżniki Zachodu. W tych samych rozdziałach napotyka się wyobrażenie pełni życia na Zachodzie i jego niemożliwości w Polsce. Paryż jest synonimem ludzkiego szczęścia oraz wolności i kojarzy się z bogactwem zmysłów i koloru ${ }^{22}$, Polska natomiast okazuje się krajem melancholii, nienormalności i szarych tonacji: „Nie chciałem wracać pod melancholijne niebo z jego ciężkimi chmurami i krakaniem wron, między smutne krajobrazy"23.

Paryż i Francja oznaczają przede wszystkim niedostępną wielkość, Paryż to „stolica mocarstwa” ${ }^{24}$ i tym podobne. Jako autodefinicja pojawia się słowo

18 Opisywaną powyżej strukturę komunikacyjną wyodrębnił u Michela Montaigne’a Karlheinz Stierle. Można ją uznać za paradygmatyczną cechę gatunkową esejów nawiązujących formą do Esejów Montaigne'a. Zob. K. Stierle, Gespräch und Diskurs. Ein Versuch im Blick aufMontaigne, Descartes und Pascal [w:] Das Gespräch. Poetik und Hermeneutik, Bd. XI, red. K. Stierle, R. Warning, München 1984, s. 297-333.

19 Trzeba jednak zaznaczyć, że osiągana za pomocą kompromisu równowaga nie zawsze jest w Rodzinnej Europie celem Miłosza. Tak jest w wypadku tworzonych przez niego obrazów Rosji i Niemiec. Obraz Niemiec zdominowany jest przez wspomnienia czasów nazistowskiej okupacji i traumatyczne przeżycia wojenne poety. Bez wątpienia z dzisiejszego punktu widzenia obrazy Rosji i Niemiec w Rodzinnej Europie posiadają istotne deficyty. Ponieważ obnażają one jednak realne i historycznie uzasadnione lęki, posiadają moim zdaniem niezaprzeczalną wartość i mogą stać się zarodkiem dyskusji w szerszym gronie. O obrazie Rosji w Rodzinnej Europie - zob. M. Zemła, Mitosz, Mickiewicz, Rosja, „Pamiętnik Literacki” 2014, nr 1, s. 45-83.

20 Różne oceny Francji i Paryża w dziele Miłosza opisała obszernie Beata Tarnowska (zob. taż, dz. cyt., s. 122-136). W moim artykule zajmuję się wyłącznie logiką eseistycznego wywodu Miłosza w Rodzinnej Europie.

21 C. Miłosz, Rodzinna Europa, dz. cyt., s. 80.

22 Tamże, s. $186 \mathrm{n}$.

23 Tamże, s. 209.

24 Tamże, s. 190. 
„barbarzyńca”25, które wkrótce tak chętnie podchwycone zostanie przez Zbigniewa Herberta ${ }^{26}$. Te dobrze znane ze stereotypów antynomie spotyka się również w późniejszych dziełach Miłosza, przy czym mogą być one opatrywane różnymi znakami ${ }^{27}$. Wyrażany tu prawie bezgraniczny podziw dla Zachodu, ściśle związany z uczuciem własnej drugorzędności, nie stanowi dobrej podstawy do zjednoczenia, nie może też zapewnić ciepła, którego oczekuje się od rodziny i o którym mowa w tytule książki. Apetyt młodego człowieka jest wielki, stąd również jego nadzieje, które jednak na razie określić należy jako przesadne: „Ambicja zdobycia istoty trudno dostępnej nieraz przekształca się w miłość" 28 . Tymczasem jego uczucia okazują się ambiwalentne: przyznaje wprawdzie chętnie, że jego część Europy jest „gorsza”, jednak obojętność „lepszego” Zachodu wobec jej społecznych problemów (których widomym znakiem są włóczący się po Paryżu bezrobotni z ,jego” części Europy, spotykani przez Miłosza także w Palais du Peuple, nocnej kwaterze Armii Zbawienia) oraz czyhających zagrożeń politycznych budzą w nim gwałtowny opór. Jego agresja znajduje wyraz w fantazjach o przemocy, które pobudza widok zamożnych i zadowolonych z siebie:

Gdyby tak móc wywlec ubrylantowane baby z ich limuzyn, kopać je w tyłek, kazać im pełzać na czworakach! Wziąłbym odwet za tych z obozu (czy może pod pozorem sprawiedliwości za siebie?) ${ }^{29}$.

Ten Zachód, wyniosły i obojętny, wyposażony przez młodego bohatera w wyśrubowane pojęcie kultury, nie nadaje się na ojczyznę i nie można w nim poczuć się jak w domu - ani realnie, ani choćby mentalnie. Nie lepiej jest również w wypadku wschodniej ojczyzny Miłosza, czy też dokładnie - polskiego państwa między obiema światowymi wojnami. Młody człowiek w widoczny sposób nie może uporać się ze skomplikowaną rzeczywistością swojego kraju, jego problemami społecznymi i politycznymi:

Polska nam ciążyła. Mieszkać w niej znaczyło jak chodzić po tafli lodu - a pod nią wykrzywiały się miliony zdeformowanych, koszmarnych twarzy. Brak jednolitego wzorca uniemożliwiał odbiór człowieka ,jako takiego" - na pierwszy plan wysuwał się jego status: inteligent, chłop, Żyd. I nie polityka okresu naszego dzieciństwa ponosiła za to odpowiedzialność, ale stulecia ${ }^{30}$.

\footnotetext{
Tamże, s. 195.

Z. Herbert, Barbarzyńca w ogrodzie, Warszawa 1962.

Liczne przykłady podaje Tarnowska. Zob. taż, dz. cyt., s. 122-136.

C. Miłosz, Rodzinna Europa, dz. cyt., s. 187.

Tamże, s. 203.

Tamże, s. 187.
} 
Brakuje tu wyraźnie koncepcji, która mogłaby wyjaśnić różnorodną historię regionu, uczynić współczesność znośną dla wszystkich jego mieszkańców, a jednocześnie zawierałaby projekt nadający sens ich wspólnemu życiu. Jak się zdaje, bohater już wtedy był wygnańcem, bez możliwości zadomowienia się w ówczesnej Polsce lub na Zachodzie. Brakowało mu poczucia wewnętrznego i zewnętrznego porządku, który jest podstawą zakorzenienia:

Otaczające nas w dzieciństwie rzeczy rozumieją się same przez się, jednak jeżeli wirują jak okruchy w kalejdoskopie, bez ustanku przybierając inne pozycje, niemało energii musi zużywać się na samo wrośnięcie stopami w grunt, żeby nie upaśćc ${ }^{1}$.

Ten porządek zostaje w końcu w Rodzinnej Europie zbudowany, ale zanim do tego dojdzie, bohater w następnych latach utraci całkowicie ziemię pod nogami. Wymknie mu się zresztą nie tylko ziemia, lecz cały kosmos. Lata trzydzieste, druga wojna światowa, zagłada Żydów, układ w Jałcie, w wyniku którego „jego” Europa dostanie się za żelazną kurtynę, a także zachowanie „postępowych” elit Europy - wszystko to zostanie uznane przez poetę za początek katastrofy, która kontynuowana miała być po wojnie, aby - zdaniem Miłosza i podmiotu jego dzieła - rozprzestrzeniać się dalej na coraz to nowych terenach. Jest to czas, w którym gnoza i jej eschatologia zawładnęły Miłoszem, a zatem i jego podmiotem, niemal bez reszty. Również Tygrys (Kroński), przyjaciel i przez pewien czas mentor Miłosza, dostrzega katastrofę kultury europejskiej; dla niego jest ona jednak tylko prymitywną fazą początkową nowej ery, po której nastąpi epoka nowego, lepszego „chrześcijaństwa” 32 . Miłosz i jego bohater w Rodzinnej Europie wydają się przynajmniej rozważać tę koncepcję.

Wyposażony w tę nową , wiarę" bohater ten - w pierwszych powojennych latach dyplomata w służbie komunistycznego państwa - feruje wyroki na temat Zachodu. Widziany z tej perspektywy Paryż okazuje się „odsunięty na bok przez bieg historii, aleksandryjski, z przechowywania swoich skarbów czerpiący rację istnienia, gotowy do nowej funkcji miasta zabytku"33. Jeszcze dobitniej sformułowany jest sąd o Paryżu na początku rozdziału Tygrys:

Paryż po Ameryce przypominał mi widziane przed wojną śpiące Bruges. Zamiast kanałów - Sekwana, mogłyby pływać po niej łabędzie i bluszcz mógłby już okryć stare kamienie ${ }^{34}$.

Paryż, a razem z nim Zachód, są już tutaj ruiną in spe, stan ich porównywalny jest, jak to dalej Miłosz wywodzi, do finalnej fazy rzymskiego imperium.

\footnotetext{
31 Tamże, s. 80.

32 Tamże, s. $303 \mathrm{n}$.

33 Tamże, s. 190.

34 Tamże, s. 307.
} 
Katastrofa Europy wydaje się stać u jej progu. Sytuacja bohatera nie poprawiła się przy tym, a raczej wręcz pogorszyła, jednak jego kompleks niższości zamienił się teraz w poczucie przewagi: uważa, że należy do niewielkiej grupy wtajemniczonych, znajdujących się w posiadaniu wiedzy o przyszłości kontynentu.

Nie jest tutaj możliwe pokazanie skomplikowanej drogi, którą Miłosz dochodzi do wyobrażenia o jedności Europy, rozwijanego pod koniec dzieła. Jedność ta jest wynikiem przezwyciężenia zarówno opartego na gnozie katastrofizmu, jak i utopistycznego myślenia o proweniencji heglowskiej, reprezentowanego przez Krońskiego. Można powiedzieć, że Europa oznacza dla poety przede wszystkim pewien sposób obchodzenia się z czasem, określone rozumienie historii ${ }^{35}$. Odnalezienie się w historii oznacza dla Miłosza jednocześnie odnalezienie się w Europie. Pojęcie Europy rozwijane przez poetę pod koniec dzieła opiera się na przesłankach teologicznych, główną inspiracją są dla niego filozofia, szczególnie Pamiętnik Stanisława Brzozowskiego ${ }^{36}$, a także poetyckie koncepcje Cypriana Kamila Norwida. Podstawą tego pojęcia jest przekonanie, że historia ludzka pozostaje w tajemniczym związku z historią Zbawienia. Człowiek musi wierzyć, że jego - nawet niewielkie - czyny zbliżają ludzkość do tego wielkiego celu. Stąd, zdaniem Miłosza, wynikają pozytywne oczekiwanie, które stanowi fundament kultury europejskiej, oraz jej zdolność do odnowy. Toteż Francja, która faktycznie po drugiej wojnie światowej utraciła wiele ze swej politycznej potęgi, widziana jest teraz przez Miłosza przede wszystkim z perspektywy zdolności do odrodzenia swej kultury: „Jej symboliczny sens jako rdzenia Europy nie pozwala jej nigdy potępić, bo z każdego popiołu lęgnie się tutaj Feniks"37. Kulturę postrzega się przede wszystkim - podobnie jak u Brzozowskiego i Norwida - z punktu widzenia pracy; również w sztuce podziwia poeta w pierwszej kolejności rzemieślniczą doskonałość. Miłosza interesuje teraz zwłaszcza tajemniczy związek między codziennymi czynnościami, wykonywanymi przez przeciętnego człowieka a historią wielkich czynów i wydarzeń:

Po kilku latach dążenia naprzód bez światła znów moja stopa dotknęła gruntu i odzyskałem zdolność do życia w teraz, w chwili, a w niej, wyższe nad wszelkie możliwe Apokalipsy, splecione wzbogacały się wzajemnie przeszłość i przyszłość. (...) Ale, inaczej niż w Ameryce, leczyła mnie nie tylko natura. W swój ciepły uścisk brała mnie Europa i jej kamienie ciosane ręką minionych pokoleń, tłum jej twarzy

35 Bardziej wyczerpująco piszę na ten temat w mojej książce (M. Zemła, Der polnische Essay und seine kulturmodellierende Funktion. Jerzy Stempowski i Czestaw Mitosz, München 2009, s. 195-242). Zob. też wesję skróconą: taż, „Tygrys”: gnoza polityczna, „Postscriptum Polonistyczne" 2011, nr 2, s. 161-190.

36 Por. C. Miłosz, Cztowiek wśród skorpionów, „Dzieła zebrane”, Kraków 2000, szczególnie zaś komentarze Miłosza do fragmentów Pamiętnika Brzozowskiego (1913) na s. 124 n. O wpływie Brzozowskiego i Norwida na koncepcję historii w Rodzinnej Europie piszę w mojej książce (M. Zemła, Der polnische Essay..., dz. cyt., s. 231-242).

37 C. Miłosz, Rodzinna Europa, dz. cyt., s. 185. 
wyłaniających się z rzeźbionego drzewa, z malowideł i złotem wyszywanych tkanin koiły, włączały mój głos pomiędzy jej stare wezwania i przysięgi, pomimo mego buntu przeciwko jej rozdarciu i chorowitości. Pomimo wszystko, rodzinna Europa ${ }^{38}$.

\section{Podobna zmiana następuje u Miłosza także w widzeniu Paryża:}

Najdziwniejsze dla mnie dzisiaj w Paryżu jest to, że ciągle jest. Przemijalność człowieka na tle niezmiennej natury dostarcza niewyczerpanego tematu do rozmyślań, ale jeżeli tłem są wytwory ludzkiej ręki, przeżywa się ją jeszcze mocniej. Ten cały potok oczu (...) biegnie w paryskiej architekturze bez przerwy poprzez lata. Poszczególne oczy i twarze gasną i giną, ale potok nie ustaje. (...) A zarazem to spięcie starych kamieni z ciągle odnawiającym się następstwem pokoleń przekształca się we mnie, nie wiem czemu, w obraz królów śpiących w plątaninie kamiennych lilii, jak wysuszone zimowe owady ${ }^{39}$.

Stolica Francji pojawia się w tym passusie jako miasto wieczne w tym szczególnym sensie, że zdaje się ono w wyjątkowy sposób ucieleśniać historię Europy w czasach nowożytnych, człowiek natomiast przemija, a jednocześnie jest przecież zawsze ten sam. Jego codzienne działania kojarzy się zwykle z historią długiego trwania, dla Miłosza łączą się one jednak także z wielkimi czynami historii zdarzeniowej ${ }^{40}$.

Mamy tu jednak do czynienia nie tyle z diagnozą, ile z upomnieniem szczególnie pod adresem intelektualistów - i projektem czy wizją kultury, która, choć w tradycji europejskiej dobrze zakorzeniona, nie posiada żadnej gwarancji skuteczności bez ciąłego podejmowania za nią odpowiedzialności przez

38 Tamże, s. 326 n. Pasaż ten wraz z kończącym niniejszy artykuł cytatem z Rodzinnej Europy zajmuje centralne miejsce nie tylko w wywodzie Błońskiego (tenże, dz. cyt.), lecz także w świetnym eseju Aleksandra Fiuta Guliwer dwudziestego wieku ([w:] tegoż, Po kropce, Kraków 2016, s. 46-57, tu s. 56). Nie mogłam niestety inspirować się tym tekstem, gdyż ukazał się on trzy lata po niemieckiej pulikacji niniejszego artykułu. Stąd też ślad Guliwera... jest tutaj tak nikły. Mogę tylko z przyjemnością stwierdzić pewne paralele w wysnuwanych wnioskach niemożność zakorzenienia ([Miłosz - dop. M.Z.] „nigdy i nigdzie nie czuł się u siebie”, tamże, s. 56), pamięć kultury jako Itaka („Jego ojczyzną stało się nade wszystko kulturowe dziedzictwo Europy”, tamże). Najważniejsze różnice (o ile w ogóle za dopuszczalne uznać porównywanie tej wysokiej próby literatury o literaturze z niniejszym artykułem) można by chyba sformułować tak: autor Guliwera dwudziestego wieku zajmuje się w swoim syntetycznym eseju (Rodzinna Europa jest tylko jednym z jego tematów) Miłoszem - dojrzałym, gotowym i mądrym oraz paralelami w biografii jego oraz autora i bohatera Podróży Guliwera, mnie natomiast interesują przede wszystkim podmiot Rodzinnej Europy i jego perypetie. W tym niezwykle inteligentnym, lecz początkowo rozdartym, niegotowym protagoniście, któremu udaje się jednak w końcu zdać swój mistrzowski egzamin, może się - jak sądzę - przejrzeć także niejeden dzisiejszy obywatel Europy Środkowo-Wschodniej. I nie tylko...

39 C. Miłosz, Rodzinna Europa, dz. cyt., s. 186 n.

40 Ten i podobne fragmenty Rodzinnej Europy komentuję obszerniej w mojej książce (M. Zemła, Der polnische Essay..., dz. cyt., s. 237-241). 
Europejczyków ${ }^{41}$. Trzeba również zauważyć, że w świetle tego projektu zmienia się także znaczenie Europy Środkowo-Wschodniej: jest ona teraz widziana też pod kątem swoich kulturalnych osiągnięć, bo autorami projektu są przecież myśliciele i artyści z Miłoszowej części kontynentu.

W nieco inny sposób zbliża się Miłosz do poetyckiego zjednoczenia Europy wtedy, gdy opisuje pejzaż nad rzeką Vézère oraz wzgórza wokół Saint-Émilion we francuskim departamencie Dordogne. Tutaj wyraźnie daje się rozpoznać wpływ Stanisława Vincenza, z którym Miłosz utrzymywał ożywione kontakty, szczególnie w pierwszych latach swojej emigracji ${ }^{42}$. Już w powstałych podczas drugiej wojny światowej szkicach i notatkach Vincenz próbował uczynić stare europejskie krajobrazy podstawą regionalnych tożsamości. Krajobraz taki musi być przede wszystkim kultywowany przez człowieka; życie musi być „ustabilizowane, ziemia uprawiona - bez tego nie ma delektacji krajobrazem, nie ma sztuki, to jest bardziej świadomej łączności i radości z tej przynależności” ${ }^{43}$. Jednocześnie krajobraz ten musi zachować pewną samodzielność, nie może zniknąć całkowicie za tworami ludzkiej działalności. Musi być więc nie tylko wynikiem ludzkiej pracy w perspektywie długiego trwania, lecz także odwrotnie - trzeba móc z niego wyczytać, jak zmieniał on człowieka. Vincenz wybierał krajobrazy od niezliczonych pokoleń zamieszkiwane przez wspólnoty i kształtowane przez ludzkie ręce. Po takim krajobrazie trzeba wędrować i doświadczać go za pomocą

41 Nie sposób pominąć tu rozrachuku z Paryżem, którego Miłosz dokonuje po latach w wierszu Rue Descartes (1980). Pojawia się tu jeszcze raz znany z Rodzinnej Europy młodzieńczy podmiot - „barbarzyńca w podróży/ onieśmielony przybyciem do stolicy świata”, który wkracza „W uniwersalne, podziwiając, pragnąc". Następnie opisywane są spustoszenia spowodowane odrzuceniem partykularnych tradycji na rzecz owego uniwersalizmu, utożsamianego tu z racjonalizmem czy też - jak to już opisali Max Horkheimer i Theodor Adorno - neutralnym wobec celów rozumem. Życie miasta zostaje jednak w wierszu radykalnie oddzielone od dziejów postępu, gdyż jego zmysłowość nie rymuje się z chłodnym rozumem: „Tymczasem zgodnie ze swoją naturą zachowywało się miasto (...). Wypiekając długie chleby i w gliniane dzbanki nalewając wino (...). Ponieważ to wszystko już było i zmieniło się/ W pomniki przedstawiające nie wiadomo kogo/ w ledwo słyszalne arie albo zwroty mowy (...) (C. Miłosz, Wiersze wszystkie, Kraków 2015, s. 779 n.). W wierszu wcale nie pojawia się podmiot z okresu „pogodzenia się" z Europą, o którym piszę powyżej - między „barbarzyńcą” a dniem obecnym jest swoista pustka: "Jakbym wrócił z wędrówki po krajach podziemnych”. Chodzi tu zapewne o sferę niebytu, do której zepchnięci zostali intelektualiści niepodzielający zachwytu dla rozumu i postępu, a więc także Miłosz. „I nie ma już tu i nigdzie stolicy świata” - stwierdza nieco dalej poeta. Czy jednak rozprawa z Paryżem jako stolicą postępowych idei unieważnia ożywiony w Rodzinnej Europie dialog z pamięcią kultury? Myślę, że nie. W tym drugim sensie Paryż - jak sądzę - w dalszym ciągu i zawsze do nas przemawia - również nie będąc już „stolicą świata”. O Rue Descartes pisali Beata Tarnowska (taż, dz. cyt., s. 122-125), Łukasz Tischner (tenże, Mitosz i epoka świecka [w:] Poznawanie Mitosza 3, 1998-2010, red. A. Fiut, Kraków 2011), a ostatnio Matthias Freise (tenże, Czestaw Mitosz i historyczność kultury, tłum. J. Dąbrowski, Kraków 2014, s. 262-266).

42 C. Miłosz, Przedmowa: La Combe [w:] S. Vincenz, Po stronie dialogu, t. 1, Warszawa 1983, s. 7-32.

43 S. Vincenz, Po stronie pamięci, Paryż 1965, s. 38. 
wszystkich zmysłów. Patrzenie nie wystarczy: to, co się widzi, może nas pouczyć najwyżej o tym, jak człowiek zmienił krajobraz. Niemniej ważne dla Vincenza są zmysł dotyku i odczuwanie, którego doświadcza się, stąpając po ziemi, obcując z jej wodami i oddychając powietrzem danego regionu. Jednak dotyk i czucie są dla dzisiejszego człowieka tylko wstępnym doświadczeniem, po którym musi on wyobrazić sobie, a następnie pojąć, jak praca zmienia krajobraz i jak on sam od pokoleń jest przezeń zmieniany. Vincenz był przekonany, że taki przeżyty krajobraz może być podstawą silniejszych więzi zbiorowych niż państwo czy rasa ${ }^{44}$.

Przyjrzyjmy się teraz następującemu opisowi w Rodzinnej Europie, na który wskazywał już cytowany na początku niniejszego artykułu Błoński:

Tak się złożyło, że wiele mi pomógł kraj jakby platońskiego przypomnienia, krajobrazów doznanych już przed chwilą narodzin, Dordogne, okolice tak łaskawe, że człowiek obrał dolinę Wezery za swoją siedzibę trzydzieści czy dwadzieścia tysięcy lat temu (czyżby kierując się platońskim przypomnieniem Raju?). I kiedy na pagórkach Saint-Émilion, koło miejsca, gdzie zaledwie wczoraj stały wille rzymskich urzędników, oglądałem brunatne skiby ziemi w winnicach, próbując wyobrazić sobie wszystkie ręce kiedyśs trudzące się tutaj, coś się we mnie odbywało ${ }^{45}$.

W opisywanym przez Miłosza krajobrazie znajdują się wszystkie najważniejsze składniki poetyckiej geografii Vincenza. Pejzaż ten zdominowany jest przez rzekę, która najpierw przyciągnęła człowieka, potem wpłynęła na jego sposób życia, a jednocześnie od czasów prehistorycznych zmieniana była wraz ze swoim otoczeniem. Dolina rzeki Vézère i jej okolice z porośniętymi winoroślą wzgórzami są u Miłosza przede wszystkim miejscem wielorakich prac ludzkich. Podmiot Rodzinnej Europy próbuje wyobrazić sobie „wszystkie ręce kiedyś trudzące się tutaj”. Krajobraz ten nie jest również przede wszystkim francuski - jest to dla Miłosza raczej bijące we Francji serce Europy. Ze swymi miejscami znaczących wykopalisk i kultury La Roque Saint-Christophe, Cro-Magnon, La Madeleine, Le Moustier, Les Eyzies-de-Tayac-Sireuil, malowidłami w grotach Lascaux, a także położonymi niedaleko wzgórzami St. Émilion jako świadkami cywilizacji rzymskiej (i nie tylko) dolina rzeki Vézère może zostać uznana za krajobraz par excellence europejski. Miłosz nazywa go krajem „platońskiego przypomnienia” i umieszcza w nim półmitycznego i półhistorycznego europejskiego człowieka ${ }^{46}$.

44 Tamże, s. 39.

45 C. Miłosz, Rodzinna Europa, dz. cyt., s. 327.

46 Jak pokazała Elżbieta Rybicka (zob. taż, Homo geographicus. Mitosza topografie i autol biolgeolgrafie [w:] tejże, Geopoetyka. Przestrzeń i miejsce we wspótczesnych teoriach i praktykach literackich, Kraków 2014, s. 527-546), Miłosz już wcześniej - a mianowicie w Notatniku amerykańskim, wydanym w tomie Kontynenty (Paryż 1958), ale publikowanym w prasie krajowej już pod koniec lat czterdziestych (fragmenty po raz pierwszy ukazały się w „Nowinach Literackich” 
Natomiast jeżeli przemyśleć nazwę tej rzeki, to jej konkretne topograficzne położenie okaże się może mniej ważne, niż to się mogło z początku wydawać. Miłosz mówi, że to „Wezera”, lecz ta nazwa zarezerwowana jest w języku polskim zasadniczo dla niemieckiej rzeki Weser; w przypadku Vézère używa się zwykle francuskiej nazwy oryginalnej. Ale przecież rzeka z tak jawnie obco brzmiącą nazwą nie mogłaby być określona epitetem „rodzinna”, dlatego polonizacja nazwy wydaje się zabiegiem niezbędnym. Lecz nie tylko: z jednej strony mamy tu bowiem do czynienia z polonizacją, a z drugiej - z ruchem w przeciwnym kierunku, w stronę swojskości pojętej po europejsku. Kiedy Miłosz przemianowuje Vézère na Wezerę, wskazuje przecież w ten sposób zarówno na wielką rzekę niemiecką, jak i na liczne inne europejskie rzeki, na przykład Vesdre w Belgii, Wear w północnej Anglii, Vesonze w Walii, etruską Bisenzio, francuską rzekę Besançon, norweską i szwedzką Visę, a także polską Wistę/Vistulę i litewską rzekę o nazwie Viešintà, gdyż wszystkie te nazwy pochodzą ostatecznie od indoeuropejskiego rdzenia *Uরeis- „moczyć, rozlewać, rozpływać się”, udokumentowanego prawie we wszystkich indoeuropejskich grupach językowych ${ }^{47}$.

Rolf Fieguth przypomniał, że wszystkie rzeki poetów są zawsze odbiciem ideału, którym jest rzeka ich małej ojczyzny ${ }^{48}$. Poza tym rzeka jest symbolem paradoksalnym, oznaczającym zarówno przemijanie, jak i wieczność ${ }^{49}$. Dlatego jest ona również idealnym imago dla sławnej formuły Miłosza z Traktatu poetyckiego: „Czas wyniesiony ponad czas przez czas”, która ma też charakter paradoksalny, gdyż według Miłosza droga do intuicji wieczności wiedzie przez pełne przeżycie historyczności ludzkiej egzystencji ${ }^{50}$.

z 1948 roku w numerach 8, 14 i 50, por. Nota wydawcy [w:] C. Miłosz, Kontynenty, Kraków 1999) - interesował się wpływem kultury na krajobraz: „Miłosz wypatruje sygnatur, świadczących o piętnie czasu i człowieka na tym, co pozaczasowe" (tamże, s. 534). Zmysłowe doświadczenie krajobrazu Rybicka dostrzega w tomie Widzenia nad Zatoka San Francisco (Paryż 1969). Autorka nie wspomina o możliwym wpływie Vincenza na Miłosza. Osobnego zaś studium wymagałoby przebadanie powinowactw między myśleniem o krajobrazie Vincenza a opisywaną przez Rybicką geograficzną szkołą z Berkeley i jej czołowym przedstawicielem Carlem Sauerem (uczonym uniwersyteckim w latach 1923-1957), a także (niegenetycznych) podobieństw twórczości autora Krajobrazu jako tta dziejów z pracami Roberta Davida Sacksa (R.D. Sacks, Homo Geographicus, Baltimore-London 1997). Rybicka omawia poglądy tych uczonych na s. 530-531 (Sauer) i s. 541 (Sacks).

47 J. Pokorny, Indogermanisches etymologisches Wörterbuch, Bern 1959, s. 1134; H. Krahe, Sprache und Vorzeit, Heidelberg 1954, s. 51.

48 Zob. C. Miłosz, Traktat poetycki: „Pod jabłoniami na brzegach Wezery,/ Pod jodłą Maine ścigając odbicie/ Czarnozielonych rzek swojej ojczyzny,/ Tak jak się w tłumie cudzoziemskich twarzy/ Ściga twarz jedną, kiedyś ukochaną" ([w:] tegoż, Wiersze wszystkie, dz. cyt., s. 442).

49 R. Fieguth, Flüsse und Fluss. Mitosz's Landschaftslyrik im Vergleich mit Hölderlin und Bobrowski [w:] Czestaw Mitosz im Jahrhundert der Extreme..., dz. cyt., s. 87-118.

50 Por. następujące sformułowanie Aleksandra Fiuta „do wieczności momentu dotrzeć da się - intuicją, przeczuciem - tylko przez jego wymiar historyczny”. Tenże, Moment wieczny. Poezja Czestawa Mitosza, Paryż 1987, s. 37). 
Pod koniec Rodzinnej Europy dotychczasowa opozycja między Europą Środkowo-Wschodnią a Zachodem zostaje zniesiona; obcy do tej pory Zachód okazuje się swojski. Europa jako dziedzictwo i przyszłość może zostać przyjęta w całości. Wszystkie wcześniej przebadane antynomie okazują się wobec tej możliwości zjednoczenia drugorzędne:

Polska i Dordogne, Litwa i Sabaudia, uliczki Wilna i uliczki Quartier Latin zrastały się w jedno, nie byłem przecie nikim innym niż Grekiem, który przeniósł się z jednego do drugiego miasta. Rodzinna Europa przebywała we mnie ze swoimi górami, lasami i stolicami i ta mapa uczuciowa przesłaniała zbyt doraźne kłopoty. Po kilku latach dążenia naprzód bez światła znów moja stopa dotknęła gruntu i odzyskałem zdolność do życia w teraz, w chwili, a w niej, wyższe nad wszelkie możliwe Apokalipsy, splecione wzbogacały się wzajemnie przeszłość i przyszłośćs1.

\section{Bibliografia}

Bachtin M., Czasoprzestrzeń idylliczna w powieści [w:] tegoż, Problemy literatury i estetyki, tłum. W. Cesluk-Grajewski, Warszawa 1982.

Błoński J., Europa Miłosza [w:] tegoż, Miłosz jak świat, Kraków 1998.

Fieguth R., Flüsse und Fluss. Mitosz's Landschaftslyrik im Vergleich mit Hölderlin und Bobrowski [w:] Czestaw Mitosz im Jahrhundert der Extreme. Ars poetica - Raumprojektionen - Abgründe - Ars translationis, red. A. Lawaty, M. Zybura, Osnabrück 2013.

Fiut A., Guliwer dwudziestego wieku [w:] tegoż, Po kropce, Kraków 2016 (pierwodruk [w:] Rodzinny świat Czestawa Mitosza, red. T. Bilczewski, L. Marinelli, M. Woźniak, Kraków 2014).

Fiut A., Moment wieczny. Poezja Czestawa Mitosza, Paryż 1987.

Freise M., Czestaw Miłosz i historyczność kultury, tłum. J. Dąbrowski, Kraków 2014.

Herbert Z., Barbarzyńca w ogrodzie, Warszawa 1962.

Krahe H., Sprache und Vorzeit, Heidelberg 1954.

Łukasiewicz J., Przestrzeń „świata naiwnego”. O poemacie Czestawa Mitosza „Świat” [w:] Poznawanie Mitosza 2. Część pierwsza 1980-1998, red. A. Fiut, Kraków 2000 .

Miłosz C., Człowiek wśród skorpionów, „Dzieła zebrane”, Kraków 2000.

Miłosz C., Przedmowa: La Combe [w:] S. Vincenz, Po stronie dialogu, t. 1, Warszawa 1983.

Miłosz C., Rodzinna Europa, „Dzieła zebrane”, Kraków 2001.

Miłosz C., Wiersze tom I, „Dzieła zebrane”, Kraków 2001.

Miłosz C., Wiersze wszystkie, Kraków 2015.

51 C. Miłosz, Rodzinna Europa, dz. cyt., s. 327. 
Miłosz C., Gorczyńska R., Podróżny świata. Rozmowy, „Dzieła zebrane”, Kraków 2002.

Pokorny J., Indogermanisches etymologisches Wörterbuch, Bern 1959.

Rybicka E., Homo geographicus. Mitosza topografie i auto/bio/geolgrafie [w:] tejże, Geopoetyka. Przestrzeń i miejsce we wspótczesnych teoriach i praktykach literackich, Kraków 2014.

Sacks R.D., Homo Geographicus, Baltimore-London 1997.

Stierle K., Gespräch und Diskurs. Ein Versuch im Blick auf Montaigne, Descartes und Pascal [w:] Das Gespräch. Poetik und Hermeneutik, Bd. XI, red. K. Stierle, R. Warning, München 1984.

Tarnowska B., Geografia poetycka w powojennenej twórczości Czestawa Mitosza, Olsztyn 1996.

Tischner Ł., Mitosz i epoka świecka [w:] Poznawanie Mitosza 3 (1998-2010), red. A. Fiut, Kraków 2011.

Vincenz S., Po stronie pamięci, Paryż 1965.

Zemła M., Die Einheit Europas. Einige Bemerkungen zum Ost-West-Verhältnis in „Rodzinna Europa” [w:] Czestaw Mitosz im Jahrhundert der Extreme. Ars poetica-Raumprojektionen - Abgründe - Ars translationis, red. A. Lawaty, M. Zybura, Osnabrück 2013.

Zemła M., Mitosz, Mickiewicz, Rosja, „Pamiętnik Literacki” 2014, nr 1.

Zemła M., Der polnische Essay und seine kulturmodellierende Funktion. Jerzy Stempowski i Czestaw Mitosz, München 2009.

Zemła M., „Tygrys”: gnoza polityczna, „Postscriptum Polonistyczne” 2011, nr 2. 